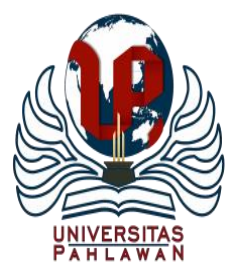

Jurnal Abdidas Volume 2 Nomor 3 Tahun 2021 Halaman 611-616

JURNAL ABDIDAS

http://abdidas.org/index.php/abdidas

\title{
Upaya Pemberdayaan Siswa dalam Pencegahan Masalah Kesehatan Jiwa Selama Pandemi Covid-19 di SMA Hang Tuah 1 Surabaya
}

\author{
Sukma Ayu Candra Kirana ${ }^{1 凶}$, Lela Nurlela ${ }^{2}$, Muh Zul Azhri Rustam ${ }^{3}$, Diyan Mutyah ${ }^{4}$, \\ A. V Sri Suhardiningsih ${ }^{5}$, Dya Sustrami ${ }^{6}$, Rossa Kurnia Ethasari ${ }^{7}$ \\ STIKES Hang Tuah Surabaya, Indonesia ${ }^{1,2,3,4,5,6,7}$ \\ E-mail: sukmaayucandrakirana@ stikeshangtuah-sby.ac.id ${ }^{1}$, lelanurlela@ stikeshangtuah-sby.ac.id ${ }^{2}$ \\ muhzulazhrirustam@stikeshangtuah-sby.ac.id ${ }^{3}$, diyanmutyah@ $\underline{\text { stikeshangtuah-sby.ac.id }}{ }^{4}$, aves @ stikeshangtuah- $^{5}$ \\ $\underline{\text { sby.ac.id }}^{5}$, dyasustrami@ stikeshangtuah-sby.ac.id ${ }^{6}$, rossakurniae@ stikeshangtuah-sby.ac.id $^{7}$
}

\begin{abstract}
Abstrak
Perubahan situasi baru akibat pandemi Covid-19 membuat sekolah ditutup dan pembatalan aktivitas siswa yang merupakan waktu penting bagi keseharian dan kehidupan siswa dalam hal ini remaja. Cemas, terisolasi dan terbebani dengan perubahan hidup akibat situasi pandemi menjadikan 99\% (2,34 miliar) anak dan remaja dibawah 18 tahun di dunia dibatasi gerak. Sebanyak $60 \%$ (1,4 miliar) anak dan remaja tersebut tinggal di negara lockdown penuh, sebanyak 7\% dan lockdown sebagian 53\%. Data tersebut tentunya dapat menjadi data kesehatan mental remaja. Tujuan kegiatan ini adalah untuk meningkatkan peran siswa dalam pencegahan masalah mental remaja selama pandemi Covid-19 di SMA Hang Tuah 1 Surabaya. Kegiatan melibatkan guru penanggung jawab UKS dan guru BP, dan siswa. Kegiatan melalui tiga tahap yaitu tahap awal yaitu sosialisasi, tahap kedua adalah pelaksanaan. Tahap pelaksanaan yang meliputi edukasi, pelatihan relaksasi, pendampingan siswa dan diakhiri tahap evaluasi kegiatan. Edukasi masalah kesehatan mental remaja di masa pandemi dilakukan melalui Zoom Meeting. Kegiatan dilaksanakan dengan baik dan diperoleh keadaan kesehatan mental siswa SMA Hang Tuah 1 Surabaya mayoritas tidak mengalami gangguan mental emosional. Kepala sekolah beserta jajaran SMA Hang Tuah 1 Surabaya mendukung keberlanjutan program pendampingan upaya pencegahan masalah kesehatan jiwa bagi siswanya.
\end{abstract}

Kata kunci: pemberdayaan siswa, pencegahan, masalah jiwa

\section{Abstract}

Changes in the new situation due to the Covid-19 pandemic led to schools being closed and the cancellation of student activities, which is an important time for daily life and students' lives, in this case teenagers. Anxious, isolated and burdened with life changes due to the pandemic situation have made 99\% (2.34 billion) of children and adolescents under 18 years of age in the world restricted from movement. $60 \%$ (1.4 billion) of these children and adolescents live in countries with full lockdown as much as $7 \%$ and partial lockdown at 53\%. Of course, this data can provide adolescent mental health data. The purpose of this activity is to increase the role of students in preventing mental problems of adolescents during the Covid-19 Pandemic at SMA Hang Tuah 1 Surabaya. The activity involved the teachers in charge of UKS and BP teachers, and students. The activity goes through three stages, namely the initial stage, namely socialization, the second stage is implementation. The implementation stage includes education, relaxation training, student mentoring and ends with the activity evaluation phase. Education on adolescent mental health problems during a pandemic is carried out through Zoom meetings. The activity was carried out well and the majority of students in SMA Hang Tuah 1 Surabaya did not experience mental emotional disorders. The school principal and the ranks of SMA Hang Tuah 1 Surabaya support the sustainability of the mentoring program to prevent mental health problems for their students.

Keywords: student empowerment, prevention, mental problems

Copyright (c) 2021 Sukma Ayu Candra Kirana, Lela Nurlela, Muh Zul Azhri Rustam, Diyan Mutyah, A. V Sri Suhardiningsih, Dya Sustrami, Rossa Kurnia Ethasari

$\triangle$ Corresponding author

Address : STIKES Hang Tuah Surabaya

Email : sukmaayucandrakirana@stikeshangtuah-sby.ac.id

ISSN 2721-9224 (Media Cetak)

DOI : https://doi.org/10.31004/abdidas.v2i3.312 
612 Upaya Pemberdayaan Siswa dalam Pencegahan Masalah Kesehatan Jiwa Selama Pandemi Covid-19 di SMA Hang Tuah 1 Surabaya - Sukma Ayu Candra Kirana, Lela Nurlela, Muh Zul Azhri Rustam, Diyan Mutyah, A. V Sri Suhardiningsih, Dya Sustrami, Rossa Kurnia Ethasari

DOI: https://doi.org/10.31004/abdidas.v2i3.312

\section{PENDAHULUAN}

Surat Edaran Mendikbud Nomor 36962/MPK.A/HK/2020 menjelaskan bahwa seluruh kegiatan belajar mengajar baik di sekolah dasar hingga perguruan tinggi menggunakan metode daring atau online sebagai upaya pencegahan penyebaran Coronavirus Disease (Covid-19). Fatkhul Mubin, M., \& Basthomi, Y. (2020) mengatakan bahwa tugas pembelajaran merupakan faktor utama penyebab stress mahasiswa selama pandemi Covid-19. Masa belajar merupakan masa transisi dari anak-anak menjadi remaja, sebagai pembentukan identitas yang harus dipenuhi agar menjadi pribadi yang tangguh dalam masa remaja yang harus berjuang dalam masa Pandemi Covid-19.

UNICEF (2020) menyebutkan bahwa situasi baru akibat pandemi Covid-19 membuat sekolah ditutup dan pembatasan aktivitas siswa, dimana aktivitas tersebut merupakan waktu penting bagi keseharian dan kehidupan siswa yang tahapan tumbuh kembang saat ini adalah remaja. Perasaan cemas, terkurung, terisolasi dan terbebani dengan tugas akademik dan perubahan hidup akibat situasi pandemi menjadikan 99\% (2,34 miliar) anak dan remaja dibawah 18 tahun di dunia dibatasi gerak. Sebanyak $60 \%$ (1,4 miliar) anak dan remaja tersebut tinggal di negara lockdown penuh sebanyak 7\% dan lockdown sebagian 53\%. Data tersebut merupakan data kesehatan mental remaja di dunia.

Cao, Fang, Hou, Han etc 2020 menjelaskan bahwa 7.143 mahasiswa menunjukkan data $0,9 \%$ ansietas berat, 2,7 \% ansietas sedang, 21,3\% ansietas ringan. Davidson, 2001 dalam Purwati, S. 2012 menyebutkan sumber stres akademik meliputi: situasi yang monoton, kebisingan, tugas yang terlalu banyak, harapan yang mengadangada, ketidakjelasan, kurang adanya kontrol, keadaan bahaya dan kritis, tidak dihargai, diacuhkan, kehilangan kesempatan, aturan yang membingungkan, tuntutan yang saling bertentangan, dan deadline tugas perkuliahan. Berdasarkan hasil wawancara dengan Wakil Kepala Sekolah Kesiswaan SMA Hang Tuah 1 Surabaya menyampaikan bahwa siswa SMA mengalami penurunan minat untuk kuliah online dan bergabung dalam perkuliahan dengan media Zoom, Google Meet. Dari total siswa 112 siswa yang diundang yang bergabung, hanya mencapai 30 sampai 50 siswa. Disinyalir siswa mengalami kejenuhan dalam proses belajar, kebosanan untuk melakukan tatap maya, bahkan stress akademik akibat pembelajaran. Data inilah yang mendorong pelaksanaan pengabdian masyarakat Departemen Jiwa dan Gerontik STIKES Hang Tuah Surabaya.

Pada masa remaja, identitas diri ini didapat sedikit-demi sedikit sesuai dengan umur kronologis dan mental age-nya. Berbagai masalah juga muncul dengan bertambahnya umur pada masa remaja. Remaja adalah masa peralihan dari anak ke masa mandiri dengan kewajiban yang lebih baik. Erickson (dalam Kroger, 2007) mengatakan bahwa masa remaja adalah individu yang telah menyelesaikan pertumbuhan dan perkembangan pada masa anak-anak. Masa remaja memiliki tiga isu fundamental yang penting dan saling terkait, sehingga tidak dapat terpisahkan 
613 Upaya Pemberdayaan Siswa dalam Pencegahan Masalah Kesehatan Jiwa Selama Pandemi Covid-19 di SMA Hang Tuah 1 Surabaya - Sukma Ayu Candra Kirana, Lela Nurlela, Muh Zul Azhri Rustam, Diyan Mutyah, A. V Sri Suhardiningsih, Dya Sustrami, Rossa Kurnia Ethasari

DOI: https://doi.org/10.31004/abdidas.v2i3.312

antara satu dengan yang lainnya. Lebih lanjut Santrock (2012:401) menjelaskan bahwa proses isu perkembangan biologis, perkembangan sosioemosional, dan perkembangan kognitif dapat mempengaruhi proses pembentukan identitas pada remaja. Bila gagal dalam membentuk identitas maka remaja tersebut akan mengalami kesulitan dalam perkembangan selanjutnya yaitu perkembangan dewasa.

Berdasarkan latar belakang tersebut, departemen jiwa dan gerontik STIKES Hang Tuah Surabaya melakukan pengabdian masyarakat kepada siswa SMA Hang Tuah 1 Surabaya tentang Pencegahan Masalah Kesehatan Mental Selama Pandemi Covid-19.

\section{METODE}

Kegiatan pengabdian masyarakat mengenai upaya pemberdayaan siswa dalam pencegahan masalah kesehatan jiwa remaja, dalam hal ini siswa SMA Hang Tuah 1 Surabaya dilakukan pada bulan Januari selama 1 minggu dengan jumlah peserta yang diharapkan 100 peserta. Namun yang hadir secara online hanya 32 siswa. Media yang digunakan adalah Google Meet untuk tatap muka secara virtual. Selain itu materi, link absen, link evaluasi telah dipersiapkan untuk menunjang selama kegiatan pengabdian masyarakat secara online berlangsung.

\section{Tahap Pertama}

Tahap pertama merupakan sosialisasi kepada kepala sekolah, guru kesiswaan dan guru UKS tentang apa, dampak, dan bagaimana pelaksanaan "Upaya Pencegahan Masalah
Kesehatan Jiwa”. Sosialisasi tersebut bertujuan untuk mengenalkan apa saja tindakan yang akan kita lakukan selama pengabdian masyarakat berlangsung. Mulai dari koordinasi ijin, penyampaian mekanisme kegiatan, penentuan jadwal pelaksanaan dan evaluasi.

\section{Tahap Kedua}

Tahap kedua merupakan tahap pelaksanaan yang terdiri dari edukasi, pelatihan relaksasi, pendampingan siswa edukasi dilaksanakan secara virtual menggunakan Zoom Meeting dengan materi "Masalah Kesehatan Jiwa Remaja Selama Pandemi Covid-19". Materi tersebut dibawakan secara langsung oleh Ketua STIKES Hang Tuah Surabaya Dr. A.V Sri Suhardiningsih, S.Kp.,M.Kes. Tahap selanjutnya adalah pelatihan relaksasi yang dilakukan secara bersama-sama dengan membentuk kelompok kelompok siswa yang terdiri dari 7-8 siswa untuk belajar tahapan relaksasi nafas dalam dengan baik. Siswa diberikan materi terlebih dahulu, diajarkan hingga mempraktikkan relaksasi napas dalam tersebut satu per satu dengan pendampingan dari dosen dan staff STIKES Hang Tuah Surabaya yang bertugas melalui ruang Zoom Meeting.

\section{Tahap Ketiga}

Tahap ketiga adalah monitoring dan evaluasi kegiatan. Proses ini juga dilakukan oleh tim pengabdian masyarakat dan siswa untuk mengetahui apakah upaya pencegahan masalah kesehatan jiwa tersebut dapat diterapkan dengan mudah oleh siswa dan guru di SMA Hang Tuah 1 Surabaya. Tim pengabdian masyarakat dan guru SMA menjadi fasilitator dalam tahap ketiga ini. 
614 Upaya Pemberdayaan Siswa dalam Pencegahan Masalah Kesehatan Jiwa Selama Pandemi Covid-19 di SMA Hang Tuah 1 Surabaya - Sukma Ayu Candra Kirana, Lela Nurlela, Muh Zul Azhri Rustam, Diyan Mutyah, A. V Sri Suhardiningsih, Dya Sustrami, Rossa Kurnia Ethasari

DOI: https://doi.org/10.31004/abdidas.v2i3.312

Monitoring evaluasi yang dilakukan adalah melakukan pertemuan secara virtual dengan mengecek perilaku tarik nafas dalam yang dilakukan siswa, pengecekan SRQ kembali setelah pelaksanaan tahap kedua pengabdian masyarakat. Hasil tersebut di tabulasi dan diobservasi kembali 1 minggu setelah tahap ketiga dilaksanakan. Apabila terdapat hasil SRQ dengan angka diatas / $>6$, maka siswa yang bersangkutan mendapat konseling khusus oleh Tim Dosen Kep Jiwa dan Gerontik STIKES Hang Tuah Surabaya.

\section{HASIL DAN PEMBAHASAN}

Kegiatan pengabdian masyarakat ini merupakan bentuk upaya pencegahan masalah kesehatan jiwa siswa yang berfokus pada perubahan perilaku masyarakat, dalam hal ini adalah kelompok khusus Remaja yang berstatus sebagai siswa SMA Hang Tuah 1 Surabaya. Upaya merubah perilaku siswa melalui pemberdayaan masyarakat ini melibatkan penggerak kesehatan guru penanggung jawab UKS dan kepala sekolah beserta staf dengan melakukan sosialisasi terhadap siswa tentang pentingnya menjaga kesehatan jiwa selama pandemi Covid-19. Melalui tahap sosialisasi, segala kebutuhan SMA akan masalah kesehatan jiwa siswa dapat diwadahi, sehingga dapat direncanakan kegiatan edukasi, pelatihan relaksasi sebagai upaya penyelesaian masalah. Kegiatan edukasi berjalan dengan baik dan siswa antusias dengan materi yang telah disampaikan.

Edukasi yang telah disampaikan merupakan informasi tentang masalah kesehatan jiwa apa saja yang terjadi pada remaja selama Covid-19, bagaimana dampak yang terjadi jika masalah tersebut tidak dapat dikontrol dan apa tindakan siswa jika ada sebagian masalah tersebut dirasakan oleh siswa. Edukasi merupakan hal yang sangat penting diberikan untuk dapat meningkatkan pemahaman siswa tentang masalah kesehatan jiwa selama pandemi Covid-19, sehingga akan sangat membantu dalam pencegahan terjadinya masalah kesehatan jiwa tersebut.

Penerapan latihan relaksasi nafas dalam juga dilakukan sebagai salah satu upaya pemecahan masalah dalam mengatasi kecemasan akibat pandemi Covid-19 dan stress akademik yang dilalui siswa. Pelatihan relaksasi ini bertujuan untuk mengedukasi siswa remaja untuk segera relaksasi apabila terpapar dengan masalah kesehatan jiwa yang telah dijelaskan pada sesi edukasi. Siswa remaja yang telah dilatih selanjutnya dimonitoring dan evaluasi pelaksanaan secara berkelompok dengan pengisian Self Reporting Quesionnare 29 oleh siswa. Hasil yang didapatkan sebanyak 32 siswa (100\%) tidak terindikasi mengalami masalah psikososial ataupun gangguan jiwa.

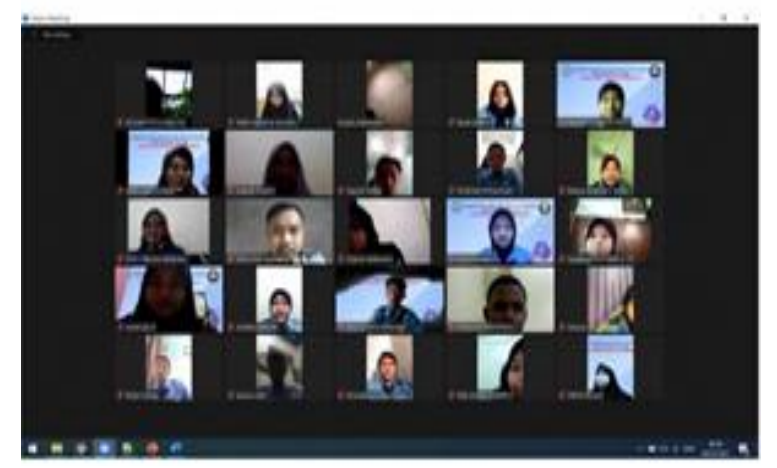

Gambar 1. Pelaksanaan Kegiatan Pengabdian Masyarakat Tahap Kedua 
615 Upaya Pemberdayaan Siswa dalam Pencegahan Masalah Kesehatan Jiwa Selama Pandemi Covid-19 di SMA Hang Tuah 1 Surabaya - Sukma Ayu Candra Kirana, Lela Nurlela, Muh Zul Azhri Rustam, Diyan Mutyah, A. V Sri Suhardiningsih, Dya Sustrami, Rossa Kurnia Ethasari

DOI: https://doi.org/10.31004/abdidas.v2i3.312

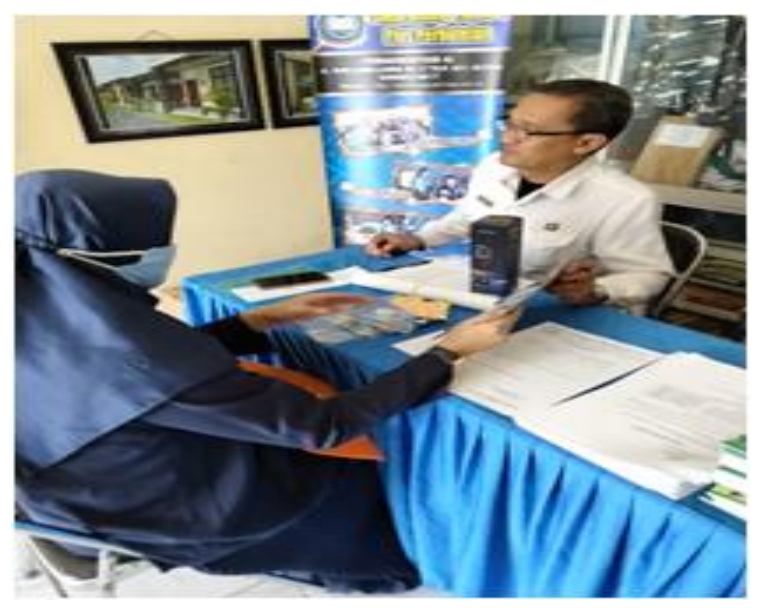

Gambar 2. Pelaksanaan Kegiatan Pengabdian

Masyarakat Tahap Pertama

Kegiatan pengabdian masyarakat ini merupakan kegiatan wajib dalam melaksanakan Tri Dharma Perguruan Tinggi yang dilakukan STIKES Hang Tuah Surabaya bekerjasama dengan SMA Hang Tuah 1 Surabaya. Melalui pengabdian ini diharapkan status kesehatan jiwa remaja di Surabaya tidak ada yang mengalami gangguan.

\section{SIMPULAN}

Kegiatan pengabdian masyarakat dengan upaya pemberdayaan siswa yang berfokus pada pencegahan masalah kesehatan jiwa remaja telah dilaksanakan. Kegiatan ini diterima oleh SMA Hang Tuah 1 Surabaya dengan baik dan antusias. Tim pengabdian, kepala sekolah, guru dan siswa saling membantu melaksanakan relaksasi napas dalam sebagai salah satu upaya mengatasi maslaah kesehatan jiwa. Evaluasi yang didapatkan tidak terdapat siswa yang mengalami gangguan mental emosional dan mayoritas hasil SRQ-29 siswa dalam kondisi tidak terdapat gangguan (skor nilai dibawah 6).

\section{Saran}

Sekolah sebaiknya bekerjasama dengan institusi pendidikan untuk mendapatkan pendidikan kesehatan dalam kesehatan fisik maupun mental, untuk menjaga status kesehatan peserta didiknya. Apalagi dalam kondisi pandemik Covid-19 yang rentan sekali mengalami masalah kesehatan baik fisik maupun mental.

\section{UCAPAN TERIMAKASIH}

1. Kepala Sekolah SMA Hang Tuah 1 Surabaya beserta guru dan staf yang telah memberikan arahan dan memfasilitasi kegiatan pengabdian masyarakat ini.

2. Siswa Siswa kelas XII SMA Hang Tuah 1 Surabaya yang telah berpartisipasi dalam kegiatan ini.

3. Dosen dan Staf STIKES Hang Tuah Surabaya yang telah berpartisipasi dalam kegiatan.

\section{DAFTAR PUSTAKA}

Kemendikbud (2020). Kemendikbud Imbau Pendidik Hadirkan Belajar Menyenangkan Bagi Daerah yang Terapkan Belajar diRumah [Internet]. [cited 2021 Apr 21]. Available from:

https://www.kemdikbud.go.id/main/blog/202 0/03/kemendikbud-imbau-pendidikhadirkan-belajar-menyenangkan-bagidaerah-yang-terapkan-belajar-di-rumah

Livana, Mubin, \& Basthomi Y. (2020) Penyebab Stres Mahasiswa Selama Pandemi Covid-19. Jurnsl Ilmu Keperawatan Jiwa, 3(2):203-8.

UNICEF. (2020). Young people take the lead on mental health [Internet]. UNICEF. Available from:

https://www.unicef.org/indonesia/coronaviru s/stories/young-people-take-lead-mentalhealth 
616 Upaya Pemberdayaan Siswa dalam Pencegahan Masalah Kesehatan Jiwa Selama Pandemi Covid-19 di SMA Hang Tuah 1 Surabaya - Sukma Ayu Candra Kirana, Lela Nurlela, Muh Zul Azhri Rustam, Diyan Mutyah, A. V Sri Suhardiningsih, Dya Sustrami, Rossa Kurnia Ethasari

DOI: https://doi.org/10.31004/abdidas.v2i3.312

Cao W, Fang Z, Hou G, Han M, Xu X, Dong J, et al. (2020). The psychological impact of the COVID-19 epidemic on college students in China. Psychiatry Res [Internet]. 2020/03/20.;287:112934. Available from: https://pubmed.ncbi.nlm.nih.gov/32229390

Purwati S .(2012). Tingkat Stres Akademik Pada Mahasiswa Reguler Angkatan 2010 Fakultas Ilmu Keperawatan Universitas Indonesia. Skripsi. Depok: Universitas Indonesia. Universitas Indonesia.

Bosma HA. (2001) Identity Development: Adolescence Through Adulthood. Identity. 2001;1(1):95-6.

Santrock JW. (2003). Adolescence: perkembangan remaja. Edisi Terj. Adelar SB, Saragih S, editors. Jakarta; 2003. 